\title{
CHARACTERIZATION OF PHENOLIC ACIDS PROFILE FROM CHILEAN RED WINES BY HIGH- PERFORMANCE LIQUID CHROMATOGRAPHY
}

\author{
LEONORA MENDOZA*1, BETTY MATSUHIRO', MARÍA J. AGUIRRE ${ }^{l}$, MAURICIO ISAACS ${ }^{2}$, GASTÓN SOTÉS ${ }^{l}$, \\ MILENA COTORAS ${ }^{1}$, RICARDO MELO'.
}

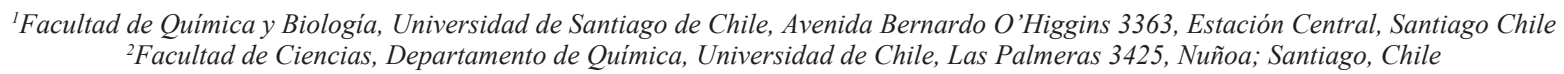

(Received: September 30, 2010 - Accepted: April 15, 2011)

\begin{abstract}
The success of Chilean wine in the international market has led to an important attention on the development of science and technology for wine differentiation, productivity, and quality. In order to report the profile of phenolic acid compounds in Chilean red wines, an SPE technique over ODS column was used followed by a reverse phase HPLC program that was developed to separate, characterize and quantify six phenolic acids (caffeic, gallic, p-coumaric, protocatechuic, syringic and vanillic acids) in four red Chilean wines varieties (Cabernet Sauvignon, Carménère, Merlot and Syrah) from grapes cultivated in the central zone of Chile. The separation was carried out on an RP C-18 column using a binary gradient elution and diode array detection.
\end{abstract}

Keywords: Chilean red wine, phenolic acids, organoleptic properties, solid-phase extraction, high performance liquid chromatography

\section{INTRODUCTION}

Chile underwent a rapid viticulture transformation in the 1990s. Its wine industry has experienced sustained growth, becoming one of the most important industries in the Chilean economy. Wines from Chile have found their way to consumers all over the world ${ }^{1}$. It is well known that the quality of the wine depends on different factors: intrinsic, such as the grape variety, and extrinsic, such as soil, weather, and winemaking techniques (e.g. time of ripening, storage methods $)^{2-5}$. The interaction of all of the factors determines a profile of compounds involved in the organoleptic characteristics of the wines ${ }^{6-9}$. Phenolic acids are one of the most important quality parameters of wine, and they contribute to characteristics such as astringency and bitternes ${ }^{10}$ Phenolic acids are secondary plant metabolites widely spread throughout the plant kingdom ${ }^{11}$. They are hydroxylated derivatives of benzoic (e.g., gallic, syringic, vanillic, and protocatechuic acids), and cinnamic acids (e.g., caffeic and p-coumaric acids) (Fig. 1), and both kinds of derivatives have their biosynthetic origin in the aromatic amino acid L-phenylalanine ${ }^{12}$.<smiles>O=C(O)c1cc(O)c(O)c(O)c1</smiles><smiles>O=C(O)c1ccc(O)c(O)c1</smiles>

2

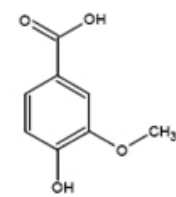

3

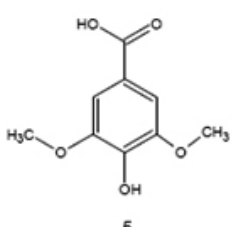

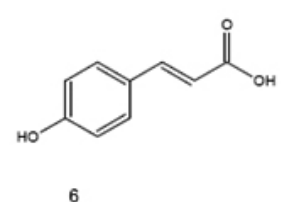

Fig. 1. The structure of phenolic acids identified in the Chilean red wine varieties (1), gallic acid; (2), protocatechuic acid; (3), vanillic acid; (4), caffeic acid; (5), syringic acid; and (6) p-coumaric acid.
In plants, benzoic and cinnamic acids derivatives are physically dispersed throughout seeds, leaves, roots, and tems ${ }^{13}$. Their roles in plants are many, including nutrient uptake, protein synthesis, enzyme activity, photosynthesis, structural components, and allelopathy ${ }^{14-16}$.

Growing interest in phenolic acids is partly due to their potential activity as protective factors against human diseases such as cancer, heart ailments, and $\mathrm{HIV}$, and partly because of their potent antioxidant capacity ${ }^{17-21}$. Although it is possible that all the properties described for red wines are the effect of mixture of compounds, more than the effect of just one type of compound ${ }^{4}$. At the same time phenolic acids receive special, attention because of their ubiquitous presence in plant-based foods, leading to their daily human consumption ${ }^{22}$. Furthermore, the role play the phenolic acids in the organoleptic properties of foods (flavor, astringency, etc.) has led to increasing analytical studies ${ }^{23}$.

In wine, phenolic acid content influences not only flavor balance, but also chemical stability and $\mathrm{pH}$, and thus the quality of wine ${ }^{24,25}$. Therefore, it is important to determine and quantify phenolic acids in wine for quality and process control.

It is well known that red wine is a complex matrix of compounds, especially a mixture of phenolic and polyphenolic compounds ${ }^{26,27}$. Because of this, in order to prevent interference among phenolic compounds and to detect phenolic compounds in very low concentrations, red wine has been fractionated into different sub-fractions before analysis $4,27-29$. For phenolic acids, separation by solid-phase extraction (SPE) over C18 (ODS) columns ${ }^{28}$ has been commonly used.

High performance liquid chromatography (HPLC) is presently the most widely used method described in the literature for the analysis of phenolic acids $^{4,23,30,31}$. However, taking into account the complex matrices of foods and the structural similarity of the various phenolic acids, it is necessary to develop new optimized HPLC methods for the analysis of those present in red wine and foods.

The major objectives of this study were (i) to propose a new optimized reverse phase HPLC program for a suitable separation of phenolic acids from red wine; (ii) to report an HPLC profile of the phenolic acids in four Chilean red wine varieties (Cabernet Sauvignon, Carménère, Merlot and Syrah); and (iii) to determine and quantify the presence of hydroxybenzoic acids (gallic, protocatechuic, syringic, and vanillic) and hydroxycinnamic acids (caffeic and p-coumaric) in these four wine varieties considering the recent studies reporting them in different types of wines ${ }^{32}$.

\section{EXPERIMENTAL}

\subsection{Materials.}

Samples of Cabernet Sauvignon, Carménère, Merlot and Syrah red wines were supplied by a local producer. The wines were produced in stainless steel tanks from grapes grown in 2005 in the Maipo Valley in the central zone of Chile. 


\subsection{Chemicals}

Caffeic, gallic, p-coumaric, protocatechuic, syringic, and vanillic acids, at pH 7.0 phosphate buffer were purchased from Sigma (St. Louis, MO, USA). Analytical grade acetic acid was purchased from Riedel-de Haën (Seelze, Germany. Methanol (HPLC grade) and double-distilled water were purchased from Merck (Darmstadt, Germany).

\subsection{Chromatographic Conditions.}

The separation of phenolic acids was performed in a Waters 2690 HPLC system equipped with a Waters $\mathrm{AF}$ on-line degasser and connected to a Waters model 996 photodiode array detector. Instrument control and data analysis were carried out using Millennium 3.20 software. Separation of phenolic acids was performed on a reverse-phase Waters Symmetry C-18 $(250 \mathrm{~mm}$ x 4.6 $\mathrm{mm}, 5 \mathrm{~mm}$ ) (Millipore, Milford, MA) column at $30{ }^{\circ} \mathrm{C}$. A gradient consisting of solvent A $(2.5: 97.5 \mathrm{v} / \mathrm{v}$ methanol-double distilled water at $\mathrm{pH} 3$ with acetic acid) and solvent B (50:50 v/v methanol-double distilled water at $\mathrm{pH} 3$ with acetic acid) was applied at a flow rate of $1 \mathrm{~mL} / \mathrm{min}$ (Table 1). Injection volume of both the standards and the wine samples was $20 \mu \mathrm{L}$.

Table 1. Gradient elution conditions.

\begin{tabular}{|c|c|c|c|}
\hline Time $(\min )$ & $\mathrm{A}(\%)^{\mathrm{a}}$ & $\mathrm{B}(\%)^{\mathrm{b}}$ & Elution \\
\hline 0 & 100 & 0 & Isocratic \\
20 & 100 & 0 & Isocratic \\
30 & 82 & 18 & Linear gradient \\
40 & 75 & 25 & Linear gradient \\
50 & 65 & 35 & Linear gradient \\
70 & 65 & 35 & Isocratic \\
\hline
\end{tabular}

${ }^{a} \mathrm{~A}$ : Methanol-double distilled water $(2.5: 97.5 \mathrm{v} / \mathrm{v})$ at $\mathrm{pH} 3$ with acetic acid ${ }^{\mathrm{b}} \mathrm{B}$ : Methanol-double distilled water $(50: 50 \mathrm{v} / \mathrm{v})$ at $\mathrm{pH} 3$ with acetic acid

2.4 Sample Preparation of Standard Solutions and Calibration Curves

An external standard method was used for quantification. Peak areas from the HPLC chromatogram were plotted against the known concentrations of stock solutions of varying concentrations. Stock solutions of each phenolic acid were prepared by accurately weighing $0.010 \mathrm{~g}$ of the standard and dissolving it in $10 \mathrm{~mL}$ of acetic acid/methanol $(90: 10, \mathrm{pH} 3)$ solution. A $10 \%$ aqueous solution of ethanol was used to mimic the wine medium. For the calibration curves the stocks solutions were diluted with water/methanol (90:10, $\mathrm{pH} 3$ ) solution to get the required concentrations. The linear range and the linear regression equations were obtained through a sequence of $50,20,10,5,2,1$, $0.5,0.2,0.1$ and $0.05 \mathrm{mg} / \mathrm{L}$ concentrations. The mean areas $(\mathrm{n}=5)$ generated from the standard solutions were plotted against concentration to establish the calibration equations.

2.5 Preparation and preconditioning of ODS column

The commercial empty polypropylene columns $(82 \mathrm{~mm}$ x $20 \mathrm{~mm})$ were filled with $5 \mathrm{~g}$ of octadecyl-functionalized silica gel (ODS RP-18, particle size $25-40 \mu \mathrm{m})$. The column was activated with $15 \mathrm{~mL}$ of methanol, washed with $50 \mathrm{~mL}$ of distilled water, and pre-conditioned with $15 \mathrm{~mL}$ of $\mathrm{pH} 7.0$ phosphate buffer before using it for the fractionation of phenolic acids from red wine.

\subsection{Fractionation of Phenolic Acid Compounds}

The procedure proposed by Sun et al. ${ }^{28}$ has been applied. Each sample of red wine was dealcoholized under reduced pressure at less than $30^{\circ} \mathrm{C}$, neutralized with $0.1 \mathrm{M} \mathrm{NaOH}$ solution to $\mathrm{pH} \approx 7.0$ (the wine color changed from red to blue), followed by addition of $\mathrm{pH} 7.0$ phosphate buffer to adjust the $\mathrm{pH}$ to exactly 7.0 . Then, $1.5 \mathrm{~mL}$ of the resulting solution was carefully loaded onto the pre-conditioned ODS RP 18 column in a flow of less than $2 \mathrm{~mL} / \mathrm{min}$. The phenolic acids were eluted with $50 \mathrm{~mL}$ of $\mathrm{pH} 7.0$ phosphate buffer.

The percent recovery of phenolic acids was estimated by comparing the individual HPLC peak areas measured for the standard solutions before and after passing through the RP 18 column.

\subsection{Evaluation of peak purity}

To check peak purity the eluates were monitored with a photodiode array detector $(\lambda=200-400 \mathrm{~nm})$. The computerized three spectra corresponding to the upslope, apex and down slope of each peak were normalized and superimposed. Peaks were considered pure when there was exact coincidence among the three spectra (match factor $\geq 99.5$ ).

\section{RESULTS AND DISCUSSION}

In accordance with previous work on phenolic acids in wine and food composition, the solid-phase extraction (SPE) technique on a C18 (ODS) column was the analytical technique selected for an optimal separation of the phenolic acids fraction from neutral compounds ${ }^{28}$. Acidic phenols and other ionizable species such as organic acids become ionized at $\mathrm{pH}$ 7. They are not absorbed by the lipophilic packing material, and to recover the fraction containing phenolic acids it is sufficient to pass a $\mathrm{pH} 7.0$ phosphate buffer through the pre-conditioned ODS RP 18 column $^{26}$. The percent recovery of phenolic acid standards ranged from $86.7 \%( \pm 6.6)$ to $98.2 \%( \pm 3.8)$ and is presented in Table 2.

Table 2. Recovery of phenolic acids standards solid-phase extraction procedure.

\begin{tabular}{|c|c|}
\hline Standard & Mean $(\%) \pm \mathrm{SD}^{\mathrm{a}}$ \\
\hline Caffeic acid & $98.2 \pm 3.8$ \\
\hline Gallic acid & $91.4 \pm 2.3$ \\
\hline p-Coumaric acid & $89.7 \pm 3.5$ \\
\hline Protocatechuic acid & $86.7 \pm 6.6$ \\
\hline Syringic acid & $95.1 \pm 5.2$ \\
\hline Vanillic acid & $92.9 \pm 4.9$ \\
\hline
\end{tabular}

To separate the phenolic acids, chromatographic conditions were optimized by first using a standard mixture of phenolic acids to ensure that the compounds were well resolved. Several experiments (elution phase and chromatographic gradient) were carried out to achieve an appropriate resolution. The separation achieved with the standard mixture is presented in Fig. 2; it shows a good resolution of the different compounds. The wavelength chosen to represent the chromatograms in Fig. 3 was $280 \mathrm{~nm}$, an intermediate value observed between the $259 \mathrm{~nm}$ of protocatechuic acid (2) and the $324 \mathrm{~nm}$ of caffeic acid (4).

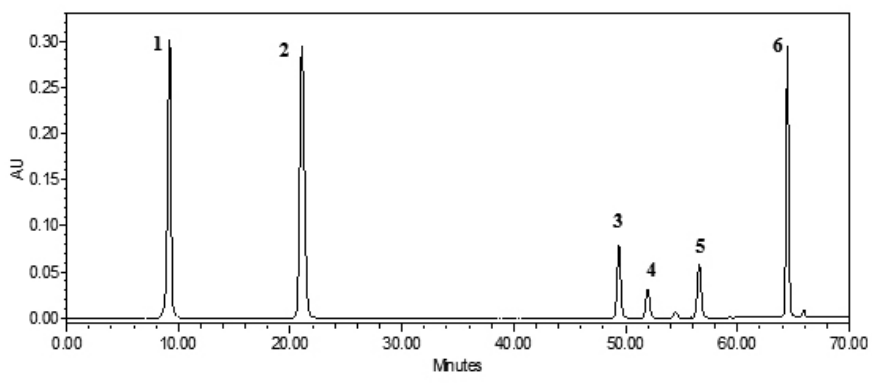

Fig. 2. HPLC Chromatogram of phenolic acids standards. Peaks are indicated as follows: (1) gallic acid,(2) protocatechuic acid,(3) vanillic acid, (4), caffeic acid, (5) syringic acid, and (6) p-coumaric acid. Detection was at $280 \mathrm{~nm}$.

The retention times, wavelengths and calibration curves of the phenolic acids standards are listed in Table 3 . Values of retention times were in agreement with those published by $\mathrm{Ho}$ et $\mathrm{al}^{32}$. Retention time depends on the intrinsic and extrinsic factors, the former related to the molecular structure of the compounds (similarities or differences between them) and the latter to the tools and machines involved in the analysis (type of stationary phase in the column, flow rate). Nowadays, the use of monolithic columns allows operation at higher flow rates, reducing the analysis time compared to the conventional RP-C18 column like the one used in this study ${ }^{33}$. 
Table 3. Analytical data: retention time, wavelength, and calibration curve of phenolic acids standards.

\begin{tabular}{|c|c|c|c|c|c|c|}
\hline & \multirow[t]{2}{*}{ Compound } & \multirow{2}{*}{$\begin{array}{c}\begin{array}{c}\text { Retention } \\
\text { time }\end{array} \\
(\min ) \\
\text { mean } \pm \mathrm{SD}^{\mathrm{a}}\end{array}$} & \multirow{2}{*}{$\frac{\lambda_{\max }^{\mathrm{b}}}{(\mathrm{nm})}$} & \multicolumn{3}{|c|}{ Calibration curve parameters ${ }^{\mathrm{c}}$} \\
\hline & & & & $\mathrm{a}( \pm \mathrm{SD})$ & $\mathrm{b}( \pm \mathrm{SD})$ & $\mathrm{r}^{2}$ \\
\hline 1 & Gallic acid & $9.216 \pm 0.24$ & 272 & $12.35 \pm 0.01$ & $0.06 \pm 0.01$ & 0.998 \\
\hline 2 & $\begin{array}{l}\text { Protocat- } \\
\text { echuic acid }\end{array}$ & $21.040 \pm 0.14$ & 259 & $17.30 \pm 0.02$ & $-0.10 \pm 0.05$ & 0.999 \\
\hline 3 & Vanillic acid & $49.405 \pm 0.18$ & 261 & $16.23 \pm 0.02$ & $-0.32 \pm 0.02$ & 0.999 \\
\hline 4 & Caffeic acid & $51.981 \pm 0.32$ & 324 & $25.45 \pm 0.01$ & $0.01 \pm 0.01$ & 0.998 \\
\hline 5 & $\begin{array}{c}\text { Syringic } \\
\text { acid }\end{array}$ & $56.588 \pm 0.21$ & 274 & $13.54 \pm 0.03$ & $1.29 \pm 0.04$ & 0.999 \\
\hline 6 & $\begin{array}{c}\text { p-Coumaric } \\
\text { acid }\end{array}$ & $64.478 \pm 0.35$ & 311 & $36.98 \pm 0.02$ & $-0.34 \pm 0.03$ & 0.998 \\
\hline
\end{tabular}

The identification of phenolic acids in Chilean red wine was achieved by comparison of both the retention time and the absorption spectra obtained for each peak with those obtained for the standards. Fig. 3 shows the chromatographic profile of phenolic acid compounds in four different types of Chilean red wines. Quantification of the phenolic acids was made measuring the peak area at the wavelength maximum and considering the percent recovery of each acid. Table 4 and Fig. 3 show that the predominant hydroxybenzoic and hydroxycinnamic acid constituents were gallic acid (1) and caffeic acid (4), respectively, in the young red wines. The highest total concentration of phenolic acid compounds was found in Merlot and Cabernet Sauvignon (Table 4).
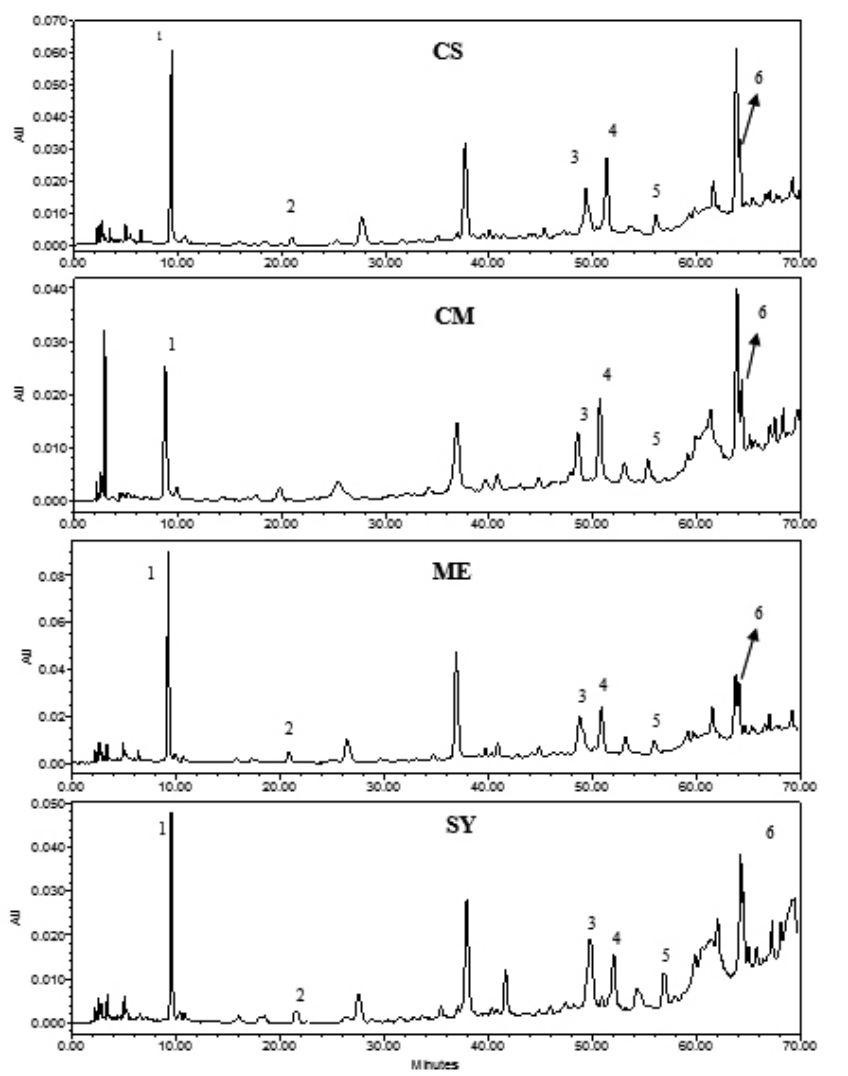

Fig. 3. HPLC chromatograms of red Chilean wines: CS, Cabernet Sauvignon; CM, Carménère; ME, Merlot and SY, Syrah. Detection was at 280 $\mathrm{nm}$.
Table 4.Phenolic acid content in wine samples.

\begin{tabular}{|c|c|c|c|c|c|}
\hline & \multirow[t]{2}{*}{ Compound } & \multicolumn{4}{|c|}{$\begin{array}{c}\text { Mean Measure Quantity }(\mathrm{mg} / \mathrm{L}) \pm \mathrm{SD}^{\mathrm{a}} \\
\text { Wines }^{\mathrm{b}}\end{array}$} \\
\hline & & CS & $\mathrm{CM}$ & $\mathrm{ME}$ & SY \\
\hline 1 & Gallic acid & $63.49 \pm 0.34$ & $35.28 \pm 0.45$ & $82.12 \pm 0.38$ & $48.86 \pm 0.65$ \\
\hline 2 & $\begin{array}{l}\text { Protocat- } \\
\text { echuic acid }\end{array}$ & $5.92 \pm 0.48$ & $\mathrm{nd}^{\mathrm{c}}$ & $10.76 \pm 0.31$ & $9.72 \pm 0.54$ \\
\hline 3 & $\begin{array}{c}\text { Vanillic } \\
\text { acid }\end{array}$ & $10.58 \pm 0.59$ & $3.52 \pm 0.33$ & $4.15 \pm 0.52$ & $11.51 \pm 0.43$ \\
\hline 4 & Caffeic acid & $21.17 \pm 0.46$ & $14.78 \pm 0.78$ & $15.40 \pm 0.47$ & $11.88 \pm 0.33$ \\
\hline 5 & $\begin{array}{c}\text { Syringic } \\
\text { acid }\end{array}$ & $7.05 \pm 0.35$ & $5.44 \pm 0.24$ & $6.91 \pm 0.32$ & $10.15 \pm 0.26$ \\
\hline 6 & $\begin{array}{c}\text { p-Coumaric } \\
\text { acid }\end{array}$ & $19.23 \pm 0.67$ & $13.19 \pm 0.42$ & $9.94 \pm 0.20$ & $10.64 \pm 0.45$ \\
\hline \multicolumn{2}{|c|}{$\begin{array}{l}\text { Total phenolic } \\
\text { acids }\end{array}$} & $127.44 \pm 2.89$ & $72.21 \pm 2.22$ & $129.28 \pm 2.20$ & $102.76 \pm 2.66$ \\
\hline
\end{tabular}

${ }^{a}$ Mean of \pm standard deviation (SD) for 5 replicates.

${ }^{\mathrm{b}}$ Wines abbreviations: CS, Cabernet Sauvignon; CM, Carménère; ME, Merlot and SY, Syrah.

${ }^{\mathrm{c}}$ nd: not detected

In a first approximation, these results agree with those reported by Del Alamo et al. for young red wine ${ }^{34}$. However, considering that the chemistry of the wine can depend on intrinsic and extrinsic factors, comparison of the phenolic compounds with other work can be quite broad.

In the present study, separation and identification of phenolic acids from red wine was achieved using the solid-phase extraction (SPE) technique over a C18 (ODS) column followed by RP-HPLC. Considering the phenolic acid fraction as the first step in red wine phenolic compound separation, future research will be focused on the separation and identification of the wide range of phenolic compounds present in red wine.

\section{CONCLUSIONS}

It can be concluded that, since the grape varieties were cultivated in the same vineyard and the corresponding wines were vinified under identical conditions, the differences in the phenolic acids profiles may be due to the grape variety. However, more wines of the same varieties and from others production areas and vintages should be studied in order to contribute more information on Chilean wine chemistry and to have a basis for comparison with the results found in this work.

\section{ACKNOWLEDGEMENTS}

The authors thank Anillo Bicentenario de Ciencia y Tecnología ACT 24 Project and 1090723 Fondecyt Project for financial support of this work

\section{REFERENCES}

1.- N. H. Beltrán, M.A. Duarte-Mermoud, M. A. Bustos, S. A. Salah, E. A. Loyola, A. I. Peña-Neira, J. W. Jalocha, J. Food Eng. 75, 1, (2006)

2.- D. I. Jackson, P. B. Lombard, Am. J. Enol. Vitic. 44, 409, (1993)

3.- G. V. Jones, R. E. Davis, Am. J. Enol. Vitic. 51, 249, (2000)

4.- I. Ginjom, B. D'Arcy, N. Caffin, M. Gidley, Food Chem. 125, 823, (2011)

5.- M. Fanzone, A. Peña-Neira, V. Jofré, M. Assof, F. Zamora, J. Agric. Food Chem. 58, 2388, (2010)

6.- $\quad$ L. Gao, B. Girard, G. Mazza, A. G. Reynolds, J. Agric. Food Chem. 45, 2003, (1997).

7.- $\quad$ E. Gómez-Plaza, R. Gil-Muñoz, J. M. López-Roca, A. Martínez, J. Agric. Food Chem. 48, 736, (2000)

8.- A. Ortega-Regules, I. Romero-Cascales, J. M. López-Roca, J. M. RosGarcía, E. Gómez-Plaza, J. Sci. Food Agric. 86, 1460, (2006).

9.- B. Sun, I. Spranger, F. Roque-do-Vale, C. Leandro, P. Belchior, J. Agric. Food Chem, 49, 5809, (2001).

10.- H. Kelebec, A. Canbas, M. Jourdes, P.L. Teissedre, Anal. Lett., 44, 991, (2011)

11.- K. M. Herrmann, Crit. Rev. Food Sci. 28, 315, (1989).

12.- K. M. Herrmann,. Plant Cell, 7, 907, (1995)

13.- J. B. Harborne, B. L. Turner, Plant Chemosystematics. Academic Press, London, 1984. 
14.- G. Montanaro, B. Dichio, C. Xiloyannis, G. Celano, Plant Sci. 170, 520, (2006)

16.- C. Brett, K. Waldron, in Physiology and Biochemistry of Plant Cell Walls, C. Brett, K. Waldron. Chapman and Hall, London, 1996 ; pp 4474.

16.- L. Djurdjevic, A. Dinic, P. Pavlovic, M. Mitrovic, B. Karadzic, V. Tesevic, Biochem Syst Ecol. 32, 533, (2004).

17.- C. V. Rao, D. Desai, B. Simi, N. Kulharni, S. Amin, B. S. Reddy, Cancer Res. 53, 4182, (1993).

18.- L. W.Morton, R. A. Caccetta, I. B. Puddey, K. D. Croft, Clin Exp Pharmacol P. 27, 152, (2000).

19.- P. J. King, G. Ma, W. Miao, Q. Jia, B. R. McDoughall, M. G. Reinecke, C. Cornell, J. Kuan, T. R. Kim, Jr. W. E. Robinson, J. Med Chem. 42, 497, (1999).

20.- C. A. Rice-Evans, N. J. Miller, G. Paganga, Free Radical Biol. Med. 20, 933, (1996)

21.- M. Pizarro, E.Lissi, J. Chil. Chem. Soc., 48, 57, (2003)

22.- M. N. Clifford, J. Sci. Food Agric. 79, 362, (1999).

23.- R. Robbins, J. Agric. Food Chem. 51, 2866, (2003).

24.- R. B. Boulton, V. L. Singleton, L. F. Bisson, R. E. Kunkee. Principles and Practices of Winemaking, Chapman and Hall, London, 1996.
25.- M. Ibern-Gómez, C. Andrés-Lacueva, R. M. Lamuela-Raventós, A. L. Waterhouse, Am. J. Enol. Vitic. 53, 218, (2002).

26.- M. Pinelo, V. F. Laurie, A. L Waterhouse, J. Agric. Food Chem. 54, 2839, (2006).

27.- B. Matsuhiro, R. Torres, E. Zuñiga, M.J. Aguirre, L. Mendoza, M. Isaacs. J. Chil. Chem Soc., 54, 405, (2009)

28.- B. Sun, M. C.Leandro, V. de Freitas, M. I. Spranger, J. Chromatogr. A. 1128, 27, (2006).

29.- A. Ghiselli, M. Nardini, A. Baldi, C. Scaccini, J. Agric. Food Chem. 46, 361, (1998).

30.- J. Simirgiotis, C. Theoduloz, P. D. S. Caligari, G. Schmeda-Hirschmann, Food Chem., 113, 377, (2009)

31.- A.-H. Liu, H. Guo, M. Ye, Y.H. Lin, J.H. Sun, M. Xu, D.A. Guo, $J$ Chromatogr. A, 1161, 170, (2007)

32.- P. Ho, T. A. Hogg, M. C. M. Silva, Food Chem. 64, 115, (1999).

33.- M. Castellari, E. Sartini, A. Fabiani, G. Arfelli, A. Amati, J. Chromatogr. $A, 973,221,(2002)$.

34.- M. Del Álamo, L. Casado, V. Hernández, J. J. Jiménez, J. Chromatogr. A. 1049, 97, (2004). 